\title{
THE TRENDS AND RISK FACTORS FOR HEPATITIS B OCCURRENCE IN ESTONIA
}

\author{
Gerli Paat ${ }^{1}$, Anneli Uusküla ${ }^{2}$, Valentina Tefanova ${ }^{3}$, Tatjana Tallo ${ }^{3,4}$, Ljudmilla Priimägi ${ }^{3}$, Kalle Ahi ${ }^{5}$ \\ ${ }^{1}$ PRAXIS Center for Policy Studies, Tallinn, Estonia \\ 2Department of Public Health, University of Tartu, Estonia \\ ${ }^{3}$ Department of Virology, National Institute for Health Development, Tallinn, Estonia \\ ${ }^{4}$ Department of Microbiology, Tumor and Cell Biology, Karolinska Institute, Stockholm, Sweden \\ ${ }^{5}$ Tallinn University of Technology, Tallinn, Estonia
}

\begin{abstract}
SUMMARY
Hepatitis B virus (HBV) infection is prevalent worldwide and is a significant cause of morbidity and mortality. This article describes the trend in HBV occurrence in Estonia from 1990 to 2005 in Estonia, with the aim of highlighting key determinants in transmission dynamics, risk groups, and possible implications for prevention and control.

A marked increase in reported numbers of new HBV cases occurred in mid 1990s (reaching 39 per 100,000 population) and decline thereafter. We present data on HBV prevalence from different population groups (persons with verified sexually transmitted infection, prisoners, medical personnel, blood donors and injection drug users). Special vaccination programmes introduced in Estonia have been successful in the prevention of HBV, however, we suggest that the main risk groups such as injection drug users (IDUs), men having sex with men (MSM) and HIV infected persons should be actively encompassed into HBV vaccination programme.
\end{abstract}

Key words: hepatitis B, epidemiology, HIV, IDU, Estonia

Address for correspondence: Gerli Paat, PRAXIS Center for Policy Studies, Health Policy, Estonia ave. 5a, 10143 Tallinn, Estonia. E-mail: gerli.paat@praxis.ee

\section{INTRODUCTION}

Hepatitis B virus (HBV) infection is a major global public health problem. There are approximately 2 billion people who have been infected worldwide, and more than 350 million of them are chronic carriers of HBV (1). Approximately 15-40\% of infected patients will develop cirrhosis, liver failure or hepatocellular carcinoma (2, 3). HBV infection accounts for 500,000 to 1.2 million deaths each year $(4,5)$ and is the 10 th leading cause of death worldwide. Hepatocellular carcinoma incidence has increased worldwide, and the disease is now the 5 th most frequent cancer, killing 300,000-500,000 people each year (6, 7).

The occurrence of HBV infection varies markedly in different geographic areas of the world, as well as in different population subgroups. According to the WHO data in 2005 the average number of $\mathrm{HBV}$ cases per 100,000 population was 3.1 in the European area with the highest incidence recorded in Iceland $(13.8 / 100,000)$ and the lowest one in Finland (0.69/100,000). HBV can be transmitted perinatally, acquired during the preschool years or by horizontal transmission in early adult life, i.e. through intravenous drug use or unprotected sexual activities (8). Other sources of infection include contaminated surgical instruments and donor organs. Health care workers, dentists and others who have frequent contact with infected blood or blood products are at highest risk. Clinically and epidemiologically relevant co-infections of HBV are described with the HCV and HIV (9). Most studies show that HIV infection leads to more aggressive hepatitis $\mathrm{C}$ or hepatitis $\mathrm{B}$ and higher risk of liver diseases, and co-infection can complicate treatment. People with liver damage due to chronic hepatitis are more likely to experience hepatotoxicity related to anti-HIV drugs (10).

In addition to IDUs, prisoners and sex workers, also MSM (men having sex with men) are considered as a high risk group for HBV infection. Several studies indicate that homosexual relationships of men will significantly contribute to the HBV infection risk $(11,12,13)$. For instance, a study conducted in United States reported the $11 \%$ average prevalence of HBV serological markers among MSM aged 15 to 22 years (14).

Hepatitis B viral infection is a preventable disease. A safe and effective vaccine, which has been available for more than 20 years, is 95\% effective in preventing the development of chronic infection. In 1991, the World Health Organization (WHO) recommended adding HBV vaccination to all national immunization programmes (1). The disease burden of HBV can be substantially reduced with public health interventions and the implementation of vaccination programs.

Estonia is confronted with an HIV epidemic driven by injection drug use that has lead to the highest increase in incidence of HIV infections in Europe (increase from 7.2 per million in 1998 to 504 in 2005) (15). In 2006, Estonia had the highest incidence of HIV in Europe with a rate of newly reported HIV cases of 49.7/100,000 inhabitants, which is about twice the rate of 27.5/100,000 inhabitants in Russia (16).

The current study sought to review the epidemiology of HBV infection in Estonia for the period of 1995 to 2005. 


\section{METHODS}

We made a review of the published literature and routine data sources available:

1. Nationwide passive surveillance system of infectious diseases (17):

In Estonia, surveillance of selected infectious diseases (HBV, HIV, HCV included) is based on the mandatory universal notification of newly identified cases to the Health Protection Inspectorate (HPI) with the same reporting principles in force throughout the last decades.

2. Database of Ministry of Social Affairs on health care statistics (18):

The Health Statistics Unit of the Department of Health Information and Analysis at the Ministry of Social Affairs of Estonia routinely collects health care statistics from all health care providers in the country.

Some unpublished reports and studies have been used.

\section{RESULTS}

\section{Epidemiology}

In the early 1990s there was a marked increase in the incidence of registered cases of HBV (and HCV). Between 1994 and 1997, there was an almost five-fold increase in the absolute numbers of people infected with hepatitis B and C. Those affected were young: among the registered new cases in 1997, 50\% of those diagnosed with $\mathrm{HBV}$ and $52 \%$ of those diagnosed with $\mathrm{HCV}$ were 15-19 years old, and with higher incidence among men (19).

The highest number of registered incidences of HBV was reported for the year 1997, 39/100,000 (16) (Fig. 1). In the early 2000s the incidence of HBV has decreased considerably - from 17.8 in 2002 to 5.8 in 2005, and 3.3 per 100,000 in 2007 (17).

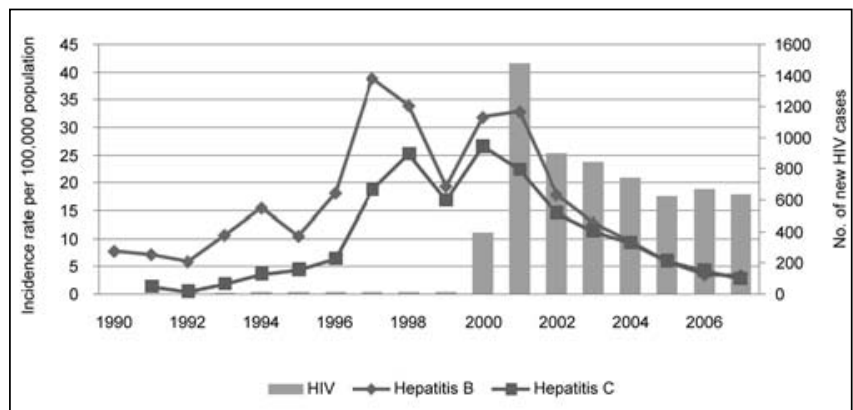

Fig. 1. Incidence of HBV and HCV infection and absolute numbers of HIV cases in Estonia, 1990-2007.

Data source: Health Protection Inspectorate, WHO database $(16,17)$

Already before 1990s the share of incidence of HBV cases attributable to blood transfusion and medical procedures had significantly declined and continued to do so in the early 2000s (the proportion of new HBV cases related to transfusion or other medical procedures was about $80 \%$ in 1980 s, $9 \%$ in 1990 s, and $3-4 \%$ by mid 2000s $(17,20)$.
It is speculated that the recent increase in the incidence of HBV (and HCV) was attributable to the spread of injecting drug use in Estonia (21-23). The epidemic of IDU preceded epidemics of HBV (and HCV, HIV). The first reports describing IDU outbreak and the growing size of IDU population in Estonia are based on field reports and expert opinions (21). In addition, growing drug use accompanied by the markedly increased numbers of patients treated for psychiatric and behavioural disorders caused by the use of illegal drugs, has more than tripled during the 1990s (from $24.5 / 100,000$ in 1995 to $82.2 / 100,000$ in 1998) (24), as well as the number of patients admitted for use of illicit opioids and alcohol during the early part of past decade (25). Majority of persons diagnosed with HBV infection among persons aged 15-19 and 20-29 years from 2002 to 2005 were IDUs $(19,26)$.

We were able to compile several research and administrative reports presenting HBV prevalence estimates from the period of 1990 to 2005 in certain population groups (Table 1). The lowest prevalence of HBV (0.1\%) was reported among blood donors in Estonia. In Estonia, donating blood is voluntary and unpaid, and blood donors are actively pre-screened. Among the 189 patients with verified STIs (C. trachomatis, $N$. gonorrhea, T. pallidum infections) enrolled between 1996 and 1998 in Tartu (the second largest town in Estonia) the prevalence of HBsAg was 1.6\%, anti-HBc $11.9 \%$, and anti-HCV $2.7 \%$. The age of all participants in the study ranged from 18-43 (with mean $=25.6$, SD 5.5), the proportion of women was 53.4\% (27). L. Priimägi et al. reported that $22 \%$ (HBV core antibodies prevalence) of the health care workers (physicians, nurses from infectious diseases, pediatrics' and surgery clinics) in Tallinn had HBV. Several studies have reported about high rates of HBV among IDUs in Estonia (28). A study that collected data on 162 IDUs visiting needle and syringe exchange programmes (NSPs) in 2004 documented high prevalence of HIV, anti-HBc, HBsAg and anti-HCV antibodies (56\%, 85.1\%, 21.3\%, and 96\%, respectively) coupled with high levels of risky injection, unsafe sexual behaviour and alcohol abuse (29). Very high HBV/HIV/HCV co-infection rates were reported. For instance among the imprisoned IDUs, the prevalence of co-infection HBV/HCV was 88.5\% (28).

\section{Molecular Epidemiology}

The genetic analysis of Estonian HBV virus strains revealed that genotype A, subtype $a d w 2$ (14\%) and genotype D, subtype ayw3 (73\%), subtypes ayw2 (3\%) and ayw4 (9\%) are circulating in Estonia (30). Infection with genotype D was mainly associated with IDUs, sexual contacts and medical procedures.

\section{Prevention}

In Estonia, the vaccination for HBV is free of charge for some population groups including health-care workers (from 1997), teenagers (from 1999) and newborns (from 2003). At the end of 2003 vaccination coverage for newborns was $46 \%$. Since 2006 , the coverage of newborns up to the age of two has reached $96.3 \%$ (31).

\section{DISCUSSION}

We have presented an overview on HBV epidemic in Estonia. In reality a process as a complex of integrated epidemics, driven 
Table 1. HBV prevalence in selected population groups

\begin{tabular}{|c|c|c|c|c|c|c|c|}
\hline \multirow{2}{*}{ Author } & \multirow{2}{*}{ Years of study } & \multirow{2}{*}{$\begin{array}{l}\text { Population } \\
\text { group }\end{array}$} & \multirow{2}{*}{$\begin{array}{c}\text { Number of } \\
\text { study subjects }\end{array}$} & \multicolumn{4}{|c|}{ The prevalence of the blood-borne infection markers tested } \\
\hline & & & & HBsAg & HBcore & HCV & HIV \\
\hline Priimägi L. (28) & 1995-1997 & $\begin{array}{l}\text { health care } \\
\text { workers }\end{array}$ & 510 & $2.6 \%$ & $22.3 \%$ & $3.9 \%$ & NTa \\
\hline Paat G. (27) & 1996-1998 & STI patients & 189 & $1,6 \%$ & $11,9 \%$ & $2,7 \%$ & NT \\
\hline Priimägi L. (28) & 1996-2000 & imprisoned IDUs & 237 & $12.6 \%$ & $82.3 \%$ & $93.7 \%$ & Neg \\
\hline Tefanova V. (19) & $2002-2003$ & $\begin{array}{l}\text { prisoners }^{b} \\
\text { anonymous } \\
\text { testing, IDU, } \\
\text { Tallinn }{ }^{c} \\
\text { anonymous test- } \\
\text { ing, IDU, North- } \\
\text { east county }{ }^{d}\end{array}$ & $\begin{array}{l}122 \\
63 \\
37\end{array}$ & $\begin{array}{l}9.8 \% \\
6.3 \%\end{array}$ & $\begin{array}{l}89.3 \% \\
68.2 \%\end{array}$ & $\begin{array}{l}100 \% \\
1.6 \%\end{array}$ & \\
\hline Uusküla A. (29) & 2004 & IDUs & 159 & $21 \%$ & $85 \%$ & $96 \%$ & $56 \%$ \\
\hline Plahhova T. (46) & 2006 & blood donors & 32254 & $0.08 \%$ & NT & $0.22 \%$ & $0.03 \%$ \\
\hline
\end{tabular}

aNT - none tested

${ }^{\mathrm{b}}$ Imprisoned IDUs from Tallinn Central Prison, all HIV-positive

by social, behavioural and biological factors following the rapid change in social structure of the country have taken place in the period of 1990-2005. Little attention was paid to the developing IDU epidemic in Estonia in early 1990s, and the epidemic of HBV, HCV that followed in the middle and late 1990s. It is also important to note that an explosive epidemic of bacterial STI (especially syphilis) took place in the early and middle 1990s (32), being most likely the marker of underlying epidemic of high risk sexual behaviour (bearing in mind the importance that neither testing and diagnosing nor system of communicable diseases notification changed in those years). The HIV epidemic that exploded in early 2000s (33) was detected quickly and public health response evolved. Major changes in political, economic and social structure have lead to significant changes in behaviour (increases in risk taking and drug abuse) that eventually contributed to the emergence of infectious diseases epidemics.

Very similar changes in occurrence of infectious diseases (blood-borne infections, sexually transmitted infectious, tuberculosis) have been described and documented from several transitional countries from the region (34-38). This is pertinent also to the data on HBV trends. The increase of reported incidence at the end of 1990s and a clear downward trend in 2000s are reported from Russian Federation, Latvia (16). Part of the decline in incidence of $\mathrm{HBV}$ can be attributable to more efficient vaccination programmes in place (vaccination of youth).

The recent HIV, HBV and HCV epidemics have been attributed to the spread of injection drug use in Estonia. According to the estimates, there were 14,000 IDUs in Estonia in 2004, which translates into a prevalence of $2.4 \%$ among people aged $15-44$ years (39), and close to half of them are HIV-infected (40, 41). In addition, the prevalence of $\mathrm{HIV} / \mathrm{HBV} / \mathrm{HCV}$ co-infections among IDUs is extremely high.

HBV infection is a well-recognized occupational risk for healthcare workers. Data on professional exposure to potentially infectious material among health care personnel from Estonia is very limited. The HBV prevalence among health care workers documented by L. Priimägi et al. (28) was surprisingly higher than those reported among patients with verified STI infection from the same time period. The study designs, aims and data collection sites of those studies were importantly different and results therefore are not directly comparable. Still, the prevention of transmission of blood borne pathogens, including HBV, from patients to healthcare workers and from healthcare workers to patients in Estonia requires full attention and further assessment. Interventions like administering hepatitis B vaccine to all susceptible healthcare workers at risk, adherence to standard (universal) precautions, appropriate cleaning and disinfection procedures, safe injection practices require urgent implementation.

Findings from studies conducted in Estonia describe high rates of sexual risk behaviour and inadequate knowledge regarding prevention of disease transmission (42), emphasizing the threat of an impending sex-related HIV and viral hepatitis epidemics. The groups under immediate threat are IDUs and their sexual partners. Moreover, also MSM are generally considered as a critical risk group for HBV infection (13).

However Estonia lacks adequate and reliable data about the prevalence of HBV infection among MSM. Still, a related study that sought to look into HIV/AIDS related knowledge and behaviour among MSM visiting gay websites found that only 37\% of MSM do not practice any risky sexual behaviour and about $21 \%$ of MSM can be characterized as exhibiting highly risky sexual behaviour (43). Hence including MSM into prevention and vaccination programmes of HBV may also be taken into consideration in Estonia.

The current HBV vaccination schedule in place is targeting infants and teenagers. The highest risk of infection, and hence being the target groups, is bared by: 1 . injection drug users, 2 . their sexual partners and 3. eventually family members.

Given that liver disease due to chronic HBV and HCV infection is becoming a leading cause of death among persons with HIV infection worldwide (44) the implementation of specific prevention interventions (such as targeted HBV vaccination of 
IDUs) and accessible treatments for HBV and HCV infection is of utmost importance in the management of those at risk for these infections and for prevention of long-term sequel such as liver disease (45). In any case, the future burden on health systems and economic productivity may well be enormous.

\section{AKCNOWLEDGEMENTS}

The authors would like to thank James Goedert, M.D. from the SUNY Downstate Medical Center, New York, USA for coordinating the hepatitis testing in the case-control study, Dr. Jack DeHovitz, MPH and Tracey Wilson, PhD.

Study was supported by Estonian Scientific Foundation grant No. 5691.

\section{REFERENCES}

1. World Health Organization [homepage on the Internet]. Hepatitis B. Fact sheet no. 204. Revised Octoíber 2000 [cited 2007 Mar 19]. Available from: http://www.who.int/mediacentre/factsheets/fs204/en/index.html.

2. Lok AS. Chronic hepatitis B. N Engl J Med. 2002 May 30;346(22):1682-3.

3. Kao JH, Chen DS. Global control of hepatitis B virus infection. Lancet Infect Dis. 2002 Jul;2(7):395-403.

4. Mahoney FJ. Update on diagnosis, management, and prevention of hepatitis B virus infection. Clin Microbiol Rev. 1999 Apr;12(2):351-66.

5. Lee WM. Hepatitis B virus infection. N Engl J Med. 1997 Dec 11;337(24):1733-45

6. Parkin DM, Bray F, Ferlay J, Pisani P. Estimating the world cancer burden: Globocan 2000. Int J Cancer. 2001 Oct 15;94(2):153-6.

7. Lavanchy D. Hepatitis B virus epidemiology, disease burden, treatment, and current and emerging prevention and control measures. J Viral Hepat. 2004 Mar;11(2):97-107.

8. Gust ID. Epidemiology of hepatitis B infection in the Western Pacific and South East Asia. Gut. 1996;38 Suppl 2:S18-23.

9. Li J, Wang J, Tian K, Wang Y, Zhang L, Huang H. Epidemiology of hepatitis $\mathrm{B}, \mathrm{C}, \mathrm{D}$ and $\mathrm{G}$ viruses and cytokine levels among intravenous drug users. J Huazhong Univ Sci Technolog Med Sci. 2006;26(2):221-4.

10. Highleyman L. HIV and hepatitis C coinfection. BETA. 2003;15(4):32-44.

11. Hart G. Factors associated with hepatitis B infection. Int J STD AIDS. 1993 Mar-Apr;4(2):102-6.

12. Atkins M, Nolan M. Sexual transmission of hepatitis B. Curr Opin Infect Dis. 2005 Feb;18(1):67-72.

13. Shepard CW, Simard EP, Finelli L, Fiore AE, Bell BP. Hepatitis B virus infection: epidemiology and vaccination. Epidemiol Rev. 2006;28(1):112-25.

14. MacKellar DA, Valleroy LA, Secura GM, McFarland W, Shehan D, Ford W, et al; Young Men's Survey Study Group. Two decades after vaccine license: hepatitis B immunization and infection among young men who have sex with men. Am J Public Health. 2001 Jun;91(6):965-71.

15. EuroHIV [homepage on the Internet]. European centre for the epidemiological monitoring and AIDS [cited 2007 May 20]. Available from: http://www.eurohiv.org/.

16. WHO Regional Office for Europe [homepage on the Internet]. The centralized information system for infectious diseases (CISID). Data Analyser 1. 9009 - Hepatitis B - Incidence (cases per 100000 population) [cited 2007 Mar 19]. Available from: http://data.euro.who.int/ cisid/?TabID=126822.

17. Health Protection Inspectorate [homepage on the Internet]. Infection diseases in Estonia [cited 2007 Mar 17]. Available from: http://www. tervisekaitse.ee/?mid=210.

18. Ministry of Social Affairs [homepage on the Internet]. Annual reports on Estonia as a whole [cited 2007 Mar 17]. Available from: http://www. sm.ee/eng/pages/index.htm.

19. Tefanova V, Tallo T, Jaroslavtsev N, Kikoš G, Krupskaja L, Lisitsina S, at al. Viral hepatitis B and C: an actual epidemiological problem in the last decade in Estonia. Eesti Arst. 2004 Nov;83(11):738-43. (In Estonian.)

20. Communicable diseases statistics in Estonia. Part 10. Tallinn: Health Protection Inspectorate; 2001. p. 64-80.

21. Kalikova N. The HIV epidemic in Estonia. In: Proceedings of the 3rd Congress of the Estonian Society of Sexually Transmitted Infections
(EUSTI). Tartu: Tartu Trükk; 2001. p. 14-5.

22. Tefanova V, Krupskaja L, Kikos G, Tallo T, Priimägi L. Study on hepatitis B and hepatitis C epidemiology in Tallinn. Eesti Arst. 1998;78(6):552-3. (In Estonian.)

23. Priimägi L, Kremerman I, Tefanova V, Tallo T, Osadtsaja G. Study on hepatitis $\mathrm{C}$ and hepatitis B infected intravenous drug users. Eesti Arst. 1998;78(6):521-3. (In Estonian.)

24. Ministry of Social Affairs [homepage on the Internet]. MOS 2005 [cited 2005 Apr 04]. Available from: http://www.sm.ee/est/pages/index.html.

25. Estonian Health Insurance Fund [homepage on the Internet]. EHIF Annua report 2005 [cited 2005 Apr 04]. Available from: http://www.haigekassa.ee.

26. Tefanova V, Tallo T, Kutsar K, Priimagi L. Urgent action needed to stop spread of hepatitis B and C in Estonian drug users. Euro Surveill. 2006 Jan 26;11(1):E060126.3.

27. Paat G. Sexual transmission of hepatitis B: a case-controls study [MSC dissertation]. Tartu: University of Tartu; 2007.

28. Priimägi L, Tefanova V, Tallo T. Emerging viral hepatitis B and C in Estonia. In: Berencsi G, Khan AS, Haloužka J, editors. Emerging Biological Threat. Washington,D.C.: IOS Press; 2005. p. 20-5.

29. Uusküla A, Heimer R, Dehovitz J, Fischer K, McNutt LA. Surveillance of HIV, hepatitis B virus, and hepatitis $\mathrm{C}$ virus in an Estonian injection drug-using population: sensitivity and specificity of testing syringes for public health surveillance. J Infect Dis. 2006 Feb 1;193(3):455-7.

30. Tallo T, Norder H, Tefanova V, Krispin T, Priimägi L, Mukomolov S, et al. Hepatitis B virus genotype D strains from Estonia share sequence similarity with strains from Siberia and may specify ayw4. J MedVirol. 2004 Oct;74(2):221-7.

31. Meriste S, Oona M, Tamm E, Lutsar I. Overview of immunisation-preventable infectious disease in Europe and in Estonia. Eesti Arst. 2006 Feb;85(2):107-26. (In Estonian.)

32. Uusküla A, Silm H, Vessin T. Sexually transmitted diseases in Estonia: past and present. Int J STD AIDS. 1997 Jul;8(7):446-50.

33. Uusküla A, Kalikova A, Zilmer K, Tammai L, DeHovitz J. The role of injecting drug use in the emergence of Human Immunodeficiency Virus infection in Estonia. Int J Infect Dis. 2002 Mar;6(1):23-7.

34. Rhodes T, Stimson GV, Fitch C, Ball A, Renton A. Rapid assessment, injecting drug use, and public health. Lancet. 1999 Jul 3;354(9172):65-8.

35. Dehne KL, Pokrovskiy V, Kobyshcha Y, Schwartländer B. Update on epidemics of HIV and other sexually transmitted infections in the newly independent states of the former Soviet Union. AIDS. 2000;14 Suppl 3: S75-84.

36. Tichonova L, Borisenko K, Ward H, Meheus A, Gromyko A, Renton A. Epidemics of syphilis in the Russian Federation: trends, origins, and priorities for control. Lancet. 1997 Jul 19;350(9072):210-3.

37. Rubins A, Rubins S, Jakabsone I. Syphilis and gonorrhoea in the Baltic countries. Sex Transm Infect. 2000 Jun;76(3):214.

38. Kelly JA, Amirkhanian YA. The newest epidemic: a review of HIV/AIDS in Central and Eastern Europe. Int J STD AIDS. 2003 Jun;14(6):361-71.

39. Uusküla A, Rajaleid K, Talu A, Abel K, Rüütel K, Hay G. Estimating injection drug use prevalence using state wide administrative data sources: Estonia, 2004. Addict Res Theory. 2007;15(4):411-24.

40. Wilson TE, Sharma A, Zilmer K, Kalikova N, Uusküla A. The HIV prevention needs of injection drug users in Estonia. Int J STD AIDS. 2007 Jun;18(6):389-91.

41. Uusküla A, McNutt LA, Dehovitz J, Fischer K, Heimer R. High prevalence of blood-borne virus infections and high-risk behaviour among injecting drug users in Tallinn, Estonia. Int J STD AIDS. 2007 Jan;18(1):41-6.

42. Wilson TE, Uusküla A, Feldman J, Holman S, Dehovitz J. A case-contro study of beliefs and behaviors associated with sexually transmitted disease occurrence in Estonia. Sex Transm Dis. 2001 Nov;28(11):624-9.

43. Lõhmus L, Trummal A. HIV/AIDS-related knowledge and behavior among MSM visiting gay websites. Tallinn: National Institute for Health Development; 2007. (In Estonian.)

44. Weber R, Sabin CA, Friis-Møller N, Reiss P, El-Sadr WM, Kirk O, et al. Liver-related deaths in persons infected with the human immunodeficiency virus: the D:A:D study. Arch Intern Med. 2006 Aug 1428;166(15):1632-41.

45. Koziel MJ, Peters MG. Viral hepatitis in HIV infection. N Engl J Med. 2007 Apr 5;356(14):1445-54.

46. Plahhova T. North-Estonian Blood Centre. 2007 Mar 1 [personal communication].

Received February, 152008 Accepted in revised form April 2, 2009 